\title{
Maize: General characteristics, importance and challenges for its production in the state of Hidalgo Mexico
}

\section{El maíz: Características generales, importancia y los retos para su producción en el estado de Hidalgo México}

GONZÁLEZ-LEÓN, Yared†, TÉLLEZ-JURADO, Alejandro, RAMÍREZ-VARGAS, María del Rocío and MERCADO-FLORES, Yuridia*

Universidad Politécnica de Pachuca, Mexico.

ID $1^{\text {st }}$ Author: Yared, González-León / ORC ID: 0000-0002-7053-4214, CVU CONACYT ID: 605765

ID $1^{\text {st }}$ Co-author: Alejandro, Téllez-Jurado / ORC ID: 0000-0002-5491-3679, CVU CONACYT ID: 30605

ID $2^{\text {nd }}$ Co-author: María del Rocío, Ramírez-Vargas / ORC ID: 0000-0003-3811-4137, CVU CONACYT ID: 266405

ID $3^{\text {rd }}$ Co-author: Miguel Angel, Anducho-Reyes / ORC ID: 0000-0003-2401-6608, CVU CONACYT ID: 89678

ID $4^{\text {th }}$ Co-author: Yuridia, Mercado-Flores / ORC ID: 0000-0003-3278-2783, CVU CONACYT ID: 122168

DOI: $10.35429 / E J E .2021 .14 .8 .1 .7$

Received January 10, 2021; Accepted June 30, 2021

\begin{abstract}
The corn production is one of the most important agricultural activities in the world, because it is one of the cereals destined for human and animal consumption, its value has influence at economic, social and cultural level. Its life cycle is divided into vegetative and reproductive, with approximately 232 days of duration. In Mexico during spring-summer and autumn-winter periods is produced, under the temporal and irrigation modalities. In the state of Hidalgo, the Mezquital Valley is the zone with higher production, in where the blackwater and high productivity hybrids are used, however, it is important to mention that the temporal production include a large extension of agricultural soils, in where its main objective is to supply this product locally. As happens at worldwide level, the corn intensive production and other crops, is made by the utilization of chemical supplies, practice used since of the green revolution, which has caused the physicochemical a biological agricultural soil degradation. The aim of this review is described the corn general characteristics and its importance in the Hidalgo Mexico state, as well as analyze the challenges to its production of the sustainable way.
\end{abstract}

\section{Resumen}

La producción de maíz es una de las actividades agrícolas más importantes del mundo, por ser uno de los cereales destinados al consumo humano y animal, su valor tiene influencia a nivel económico, social y cultural. Su ciclo de vida se divide en vegetativo y reproductivo, con aproximadamente 232 días de duración. En México se produce durante los períodos primavera-verano y otoñoinvierno, bajo las modalidades temporal y de riego. En el estado de Hidalgo, el Valle del Mezquital es la zona con mayor producción, en donde se utilizan las aguas negras y los híbridos de alta productividad, sin embargo, es importante mencionar que la producción temporal incluye una gran extensión de suelos agrícolas, en donde su principal objetivo es abastecer este producto a nivel local. Como ocurre a nivel mundial, la producción intensiva de maíz y otros cultivos, se realiza mediante la utilización de insumos químicos, práctica utilizada desde la revolución verde, que ha provocado la degradación fisicoquímica y biológica de los suelos agrícolas. El objetivo de esta revisión es describir las características generales del maíz y su importancia en el estado de Hidalgo México, así como, analizar los desafíos para su producción de manera sustentable.

Food, Agricultura sostenible, Zea mays 


\section{Introduction}

Food has been the main concern of mankind; therefore, throughout history, methods have been sought to obtain enough food to meet the needs of the population. Among the most important crops, corn (Zea mays) is one of the cereals with the highest demand worldwide for human and animal consumption, in addition to being used as raw material in a large number of industrial processes (Sámano, 2013; GonzálezLeón et al., 2020).

In Mexico, this cereal is one of the most widely used ingredients in gastronomy, with an estimated daily consumption of $343 \mathrm{~g}$ per capita. Its importance also encompasses social and cultural aspects, being a fundamental part of the traditions of a great variety of indigenous communities. The latest available data indicate that by $2020,7,481,136.87$ hectares were allocated, which generated $21,885,170.16$ tons, so more than $35 \%$ of the total arable area of the country was used, of this percentage just over $80 \%$ is rainfed, and the rest irrigated (Herrera et al., 2005; Vela et al., 2011; López et al., 2012; SIAP, 2019; SIAP, 2020).

Although Mexico is among the first ten countries that generate the highest yields worldwide, it is also an importer (Figures 1 and 2 ), which is necessary to cover the national demand mainly for white corn used for human consumption, and to a lesser extent for yellow corn used in different industries or in the preparation of animal feed (CIMMYT, 2010; SIAP, 2019). Therefore, it is necessary to look for strategies to face the current challenges of agriculture in a sustainable manner, and corn is one of the crops that could be considered as a sustainable crop. one of the crops that could be considered a priority for food sovereignty.

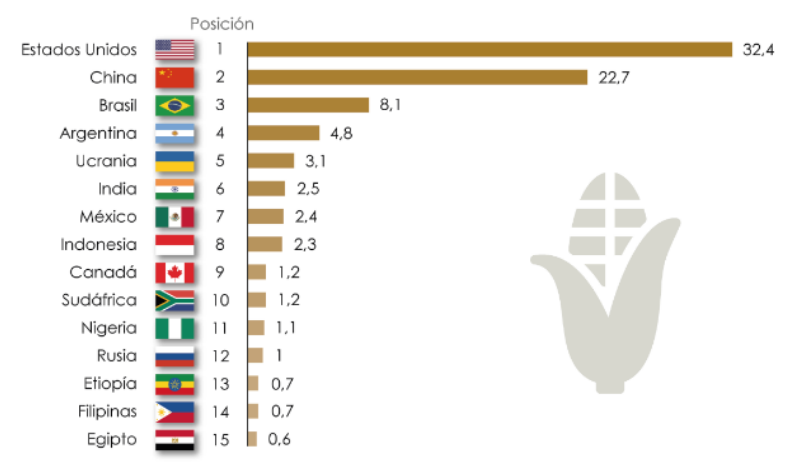

Figure 1 Contribution of different countries to world corn production in millions of tons Source: (SIAP, 2019)

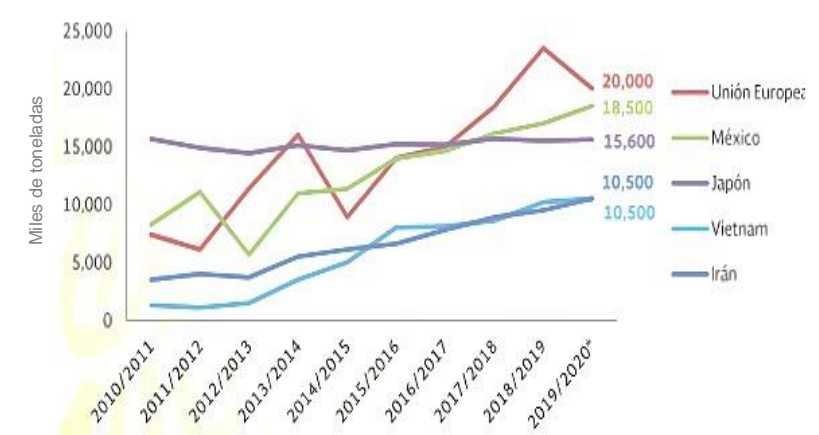

Figure 2 Major corn importing countries during the period 2010-2020

Source: (SIAP, 2019)

\section{General characteristics of corn}

Maize originated and diversified in Mexico, where it was domesticated from teosinte (Zea mays spp. parviglumis), a process that involved the selection of morphological variants, mainly in the architecture of the inflorescences, with the capacity to develop in a wide variety of agroclimatic conditions. Their classification has been carried out according to their morphology, under a hierarchical order, as shown in Table 1 (Doebley, 2004; Johnston-Monje and Raizada, 2011; Sánchez-González et al., 2018).

\begin{tabular}{|l|l|}
\hline \multicolumn{1}{|c|}{ Kingdom } & \multicolumn{2}{c|}{ Plant } \\
\hline Division & Spermatophytes or phanerogams \\
\hline Subdivision & Angiosperm \\
\hline Class & Monocotyledoneae \\
\hline Subclass & Glumiflorae \\
\hline Order & Poales \\
\hline Family & Poaceae or Gramineae \\
\hline Tribe & Maydeae \\
\hline Genus & Zea \\
\hline Species & Zea mays L \\
\hline Subspecies & Zea mays subsp Huehuetenangensis \\
& Zea mays subsp Mexicana \\
& Zea mays subsp Parviglumis \\
& Zea mays subsp Mays \\
\hline
\end{tabular}

Table 1 Taxonomic classification of maize Source: (Revelo, 2006)

This plant consists of root, stem, leaves, flowers and fruits (Figure 3). It is robust and can reach up to $4 \mathrm{~m}$ in height. It has separate male and female inflorescences within the same plant; the former has a panicle with 20-25 million pollen grains. The female inflorescence has vegetative structures called spadix, which are arranged laterally. Its vegetative cycle is divided into five stages, which are described below (Vela et al., 2011; CYMMYT, 2017; CONABIO, 2017). 
Nascence: First stage comprising the period from sowing to the appearance of the coleoptile. Its duration can be 6-8 days.

Growth: After germination, a new leaf appears every three days, until generating 5 to 6 , so that in the fourth and fifth week there will be a complete foliage.

Flowering: Period that begins between the fourth and sixth week in which the panicle is emitting pollen; with a duration of 5 to 8 days.

Fructification: After fertilization, fruiting begins, where the stigmas take on a brown color. The third week after pollination, the cob takes the definitive size and the formation of grains occurs.

Ripening and drying: In the eighth week after pollination, the grain reaches its maximum physiological maturity starting at $35 \%$ moisture, which decreases over time.

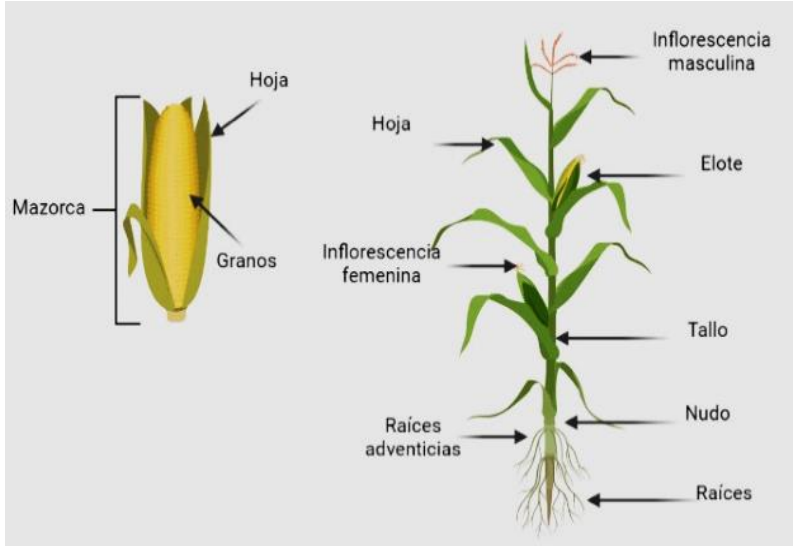

Figure 3 Schematic representation of the structure of the maize plant

Source: (Vela, 2011)

The stages of the maize cycle are the vegetative and reproductive stages, represented by the letters $\mathrm{V}$ and $\mathrm{R}$ respectively (Figure 4 ). The first has subdivisions and are designated numerically as V1, V2, up to Vn, where "n" represents the last leaf before the ear. Plant development has the following vegetative stages: emergence (EV), first leaf (V1), second leaf (V2), nth leaf (Vn) and spiking (VT). The reproductive stage comprises: Visible stigmas (R1), blistered grain (R2), milky grain (R3), doughy grain (R4), indentation (R5) and physiological maturity (R6) (Ranere et al., 2009; FAO, 2017).

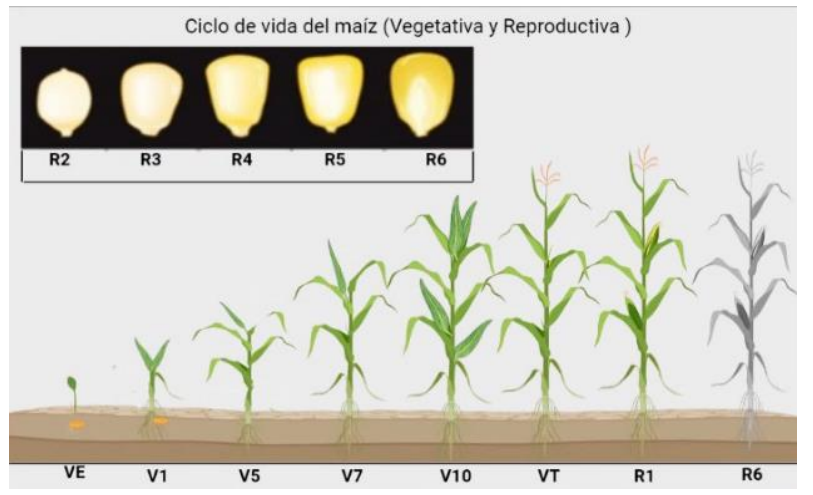

Figure 4 Schematic representation of the structure of the maize plant

Source: $(F A O, 2017)$

\section{Importance of maize in the state of Hidalgo}

In $2020,392,669.45$ ha of the surface area of the state of Hidalgo was used for agriculture, of which $58.8 \%$ was used for corn grain production. Of this percentage, $75.3 \%$ was rainfed with a yield of $1.4 \mathrm{t} / \mathrm{ha}$. For the remaining $24.7 \%$, yields of up to 8.2 t/ha were reported under irrigation (SIAP, 2019; SIAP, 2020).

Based on the above, the cultivation of this cereal is one of the main agricultural activities in the entity, with rainfed production supplying a large number of communities classified as high and very high marginalization, where, although yields are low, mainly creole maize is planted for self-consumption (MercadoFlores et al., 2016; SIAP, 2020).

On the other hand, although the area allocated to irrigated production is smaller compared to rainfed production, yields are higher, such is the case of the Valle del Mezquital, an area made up of 27 municipalities where the cultivation of this grass is intensively practiced, making use of sewage from the metropolitan area of Mexico City and technological packages that include mechanization programs, improved seeds of high productivity hybrids, in addition to chemical inputs for fertilization and elimination of pests and diseases (Mercado-Flores et al., 2016).

As happens worldwide, the crop is affected by weeds, insects and phytopathogens, with negative impact on productivity. The state of Hidalgo is under phytosanitary control of wireworm, cogollero, elotero, soldado and alfilerillo pests, as well as leafhopper and blind hen. It also includes the diseases coal ear and asphalt spot complex. 
The support is provided by the Government of Mexico in the Production for Wellbeing program. In this case, advice and inputs are given that are mostly of chemical origin; however, other health problems that are present in the different regions of the state are not contemplated (Galarza et al., 2008; Mercado-Flores et al., 2016; OSIAP, 2019).

\section{Aspects to consider that influence maize production}

Agriculture is considered the engine of the economy and will always be an indispensable sector because it generates a large number of jobs. However, there are different problems that must be addressed to ensure sufficient supply of this cereal, and thus contribute to food sovereignty (Figure 5) (González-León et al., 2020; Giller et al., 2021).

Agroecosystems are complex structures where climate is an important factor, since it determines the environmental elements and natural supplies for plant development, such as temperature, water resources, fertilization, as well as the presence of beneficial and harmful organisms (Godfray et al., 2010; Skendžić et al., 2021).

The increase in temperature in recent years has been associated with climate change. Its influence is reflected in plant development, which depends on the physiological characteristics of species that have been selected to develop in conditions different from the current ones. Another consequence is the arrival of more extensive heat waves at a global level and intense rainfall, only in some areas of the planet. On the other hand, the increase in a few degrees Celsius leads to water stress in plants, due to a deficit in soil moisture, as well as an increase in pests, weeds and diseases. Faced with this problem, agricultural producers, who generally practice traditional tillage, apply a large amount of chemical inputs to counteract the effects of different phytosanitary problems, low soil fertility and low water availability (Streck, 2005; Godfray et al., 2010; Rehman et al., 2015; Zhao et al., 2017; Skendžić et al., 2021).

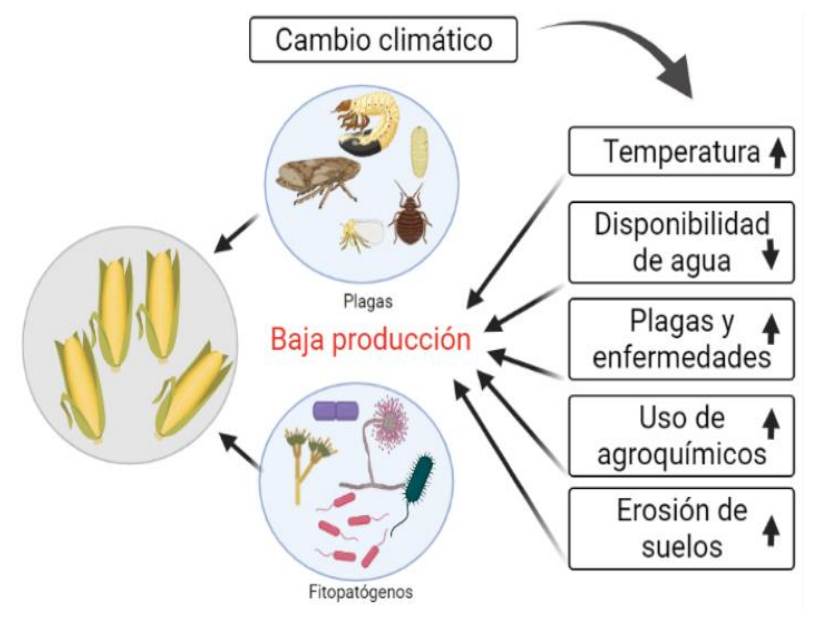

Figure 5 Schematic representation of the effects of climate change on maize production

Source: Image developed at BioRender.com

Numerous studies show that the most viable solution is to increase crop production before allocating more land area. Regenerative agriculture could be the most viable option, because it uses soil conservation as a starting point where the care of ecosystems is fundamental. Its objective is the sustainable production of food without causing negative impacts on the environment, providing social and economic benefits. Among the actions to achieve this is conservation agriculture, where zero or minimum tillage is carried out, which helps to maintain moisture by preserving the residues of the previous harvest, thus reducing dependence on this liquid. On the other hand, soil health is also reestablished by incorporating nutrients and maintaining populations of beneficial organisms. This can be improved with the use of compost and its leachates, green or animal manures, organic and biological fertilizers. In addition, chemical pesticides should be avoided and can be replaced by biological control agents, the use of insect pheromones and crop rotation. Another important aspect is to promote water percolation to avoid surface and subway contamination (González-León et al., 2020; Giller et al., 2021).

\section{Challenges for increasing maize production in the state of Hidalgo}

Taking into account that the state of Hidalgo has a mainly agricultural vocation, where maize is a priority crop (Mercado-Flores et al., 2016; SIAP, 2020), an analysis is made of the main challenges to be faced in order to increase the production of this cereal. The discussion is carried out according to the experiences of each of the authors. 
As a starting point, it should be considered that the environmental, as well as the economic and social environment, are not the same in irrigated areas compared to rainfed areas. In the first case, the cultivation of this grass is intensive with high productivity hybrids and mainly for economic purposes, while in the second case, the production of creole corn is for local consumption, and in many cases, traditions have a great influence.

On the other hand, the effect of climate change has been important, causing an increase in pests and diseases and directly affecting water availability, since rainfall for rainfed crops is scarce in some regions and very intense in others, while for irrigation, although there is availability of sewage water, levels have decreased considerably.

In this last point, the high organic load of this liquid has caused producers to disagree with the treatment of discharges, even taking into account that there are other pollutants that have important effects on the health of people and the agroecosystem.

In addition, almost all agricultural producers in the state use traditional tillage, with the increasingly frequent addition of chemical fertilizers and pesticides, which has caused soil erosion and environmental contamination that affects the health of the population living in agricultural areas.

Based on the above, the use of regenerative agriculture is proposed (Figure 6), where zero or minimum tillage would help restore the health of eroded soils and reduce dependence on water consumption by also promoting percolation. In the case of irrigation, the treatment of the discharges used is very necessary, so other forms of fertilization will have to be provided, which can also help in rainfed crops.

This could be enhanced with the help of microorganisms to control pests and diseases, as well as inoculants to enhance plant development through biological fertilization, making use of environmentally friendly products that should be designed in such a way that they can counteract the effects of climate change.

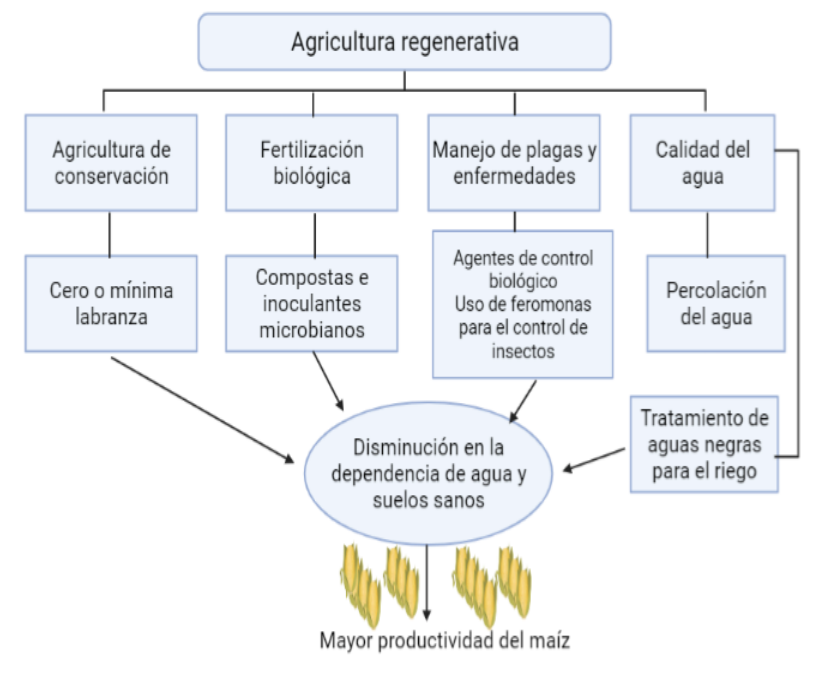

Figure 6 Schematic representation of actions that are part of regenerative agriculture as a strategy to face the challenges of corn production in the state of Hidalgo

Source: Image developed in BioRender.com

\section{Acknowledgments}

The authors would like to thank CONACyT for the Master's scholarship awarded to GonzálezLeón, Y., a student of the Postgraduate Program in Biotechnology at the Polytechnic University of Pachuca.

\section{Conclusion}

Maize cultivation in the state of Hidalgo is a priority. Regenerative agriculture could provide solutions to increase the productivity of this cereal; therefore, it is essential that the government, society, producers, and academia work together to develop ecological policies and strategies to confront the ravages caused by climate change and guarantee food sovereignty.

\section{References}

CIMMYT. (2010). Centro Internacional de Mejoramiento de Maíz y Trigo. Enfermedades del maíz: Una guía para su identificación en el campo. Accessed August 2021:

http://repository.cimmyt.org/xmlui/bitstream/ha ndle/10883/812/94349.pdf?sequence=1\&isAllo wed $=y$

CIMMYT. (2017). Centro International de Mejoramiento de Maíz y Trigo. Partes de la planta de maíz. Accessed August 2021: http://maizedoctor.org/es/partes-de-la-plantade-maiz 
CONABIO. (2017). Comisión Nacional para el Conocimiento y Uso de la Biodiversidad Maíces. Accessed August 2021: http://www.biodiversidad.gob.mx/usos/maices/ maiz.html

Doebley J. (2004). The genetics of maize evolution. Ann Rev Genet. 38:37-59. DOI: 10.1146/annurev.genet.38.072902.092425

FAO. (2017). Organización de las Naciones Unidas para la Alimentación y la Agricultura. Morfología del maíz tropical. Accessed August 2021:

http://www.fao.org/docrep/003/x7650s/x7650s0 4.htm

Galarza MJM; Miramontes PCU; Cruz DMS; Gómez VMM; Ortíz PME; Entzana TAM; Suárez HCY; Santillán MV. (2008). Situación actual y perspectivas del maíz en México 19952012.

http://www.financierarural.gob.mx/informacion sectorrural/Documents/Documentos\%20de\%20 SIAP/PerspectivasMa\%C3\%ADz1996a2012.pd f. Consultado en agosto 2021.

Giller KE; Hijbeek R; Andersson JA; Sumberg J. (2021). Regenerative agriculture: an agronomic perspective. Outlook Agri. 50:13-25. DOI: $10.1177 / 0030727021998063$

Godfray HC; Beddington JR; Crute IR; Haddad L; Lawrence D; Muir J.F; Pretty J; Robinson S; Thomas SM; Toulmin C. (2010). Food security: the challenge of feeding 9 billion people. Science. 327:812-818. DOI: $10.1126 /$ science. 1185383

González-León Y; Anducho-Reyes MA; Cartagena-Luna A; Mercado-Flores Y. (2020). Capítulo 10. Agricultura sostenible: herramienta para la soberanía alimentaria. En: "Mujeres en la Ciencia", Handbooks T-VIII. (Marroquín JA; Olivares-Ramírez JM; Cruz-Carpio LE; Bautista-Jiménez A. eds). ECORFAN-Mexico, S.C. México. pp. 142-153. DOI:10.35429/H.2020.8.142.153

Herrera JP; Cadena P; San-Clemente A. (2005). Diversidad de la artropofauna en monocultivo y policultivo de maíz (Zea mays) y habichuela (Phaseolus vulgaris). Boletín del Museo de entomología de la Universidad del Valle. 6:2331.
Johnston-Monje D; Raizada MN. (2011). Conservation and diversity of seed associated endophytes in Zea across boundaries of evolution, ethnography and ecology. PloS One 6:e20396. DOI: 10.1371/journal.pone.0020396

López MSL; García NG; Ibarra GBN. (2012). El maíz (Zea mays L.) y la cultura Maya. Biotecnia. $14: 3-8$.

Mercado-Flores Y; Cartagena-Luna A; SanchezMaya HE; Pérez-Camarillo JP; Ortega-Bernal J; Álvarez-Cervantes J; Anducho-Reyes MA. (2016). El Carbón de la espiga del maíz en el Valle del Mezquital. En: Biotecnología y Alimentos en Hidalgo: Transitando a la Bioeconomía. (Batalla-Díaz L; Gómez-Aldapa CA; Castro-Rosas J; Téllez-Jurado A. eds). Amalgama Arte S.A. de C.V. pp. 105-116.

OSIAP (2019). Organismos de Sanidad e Inocuidad Agroalimentaria para Productores. CAMPAÑAS FITOSANITARIAS. http://osiap.org.mx/senasica/sectorestado/hidalgo/Agricola. Consultado en agosto 2021.

Ranere AJ; Piperno DR; Holst I; Dickau R; Iriarte J. (2009). The cultural and chronological context of early Holocene maize and squash domestication in the Central Balsas River Valley, Mexico. PANS. 106: 5014-5018. DOI: 10.1073/pnas.0812590106

Rehman MU; Rather GH; Gull Y; Mir MR; Mir MM; Waida UI; Hakeem KR. (2015). Effect of climate change on horticultural crops. En: Crop Production and Global Environmental Issues (Hakeem KR. Ed). Springer International Publishing. Cham, Switzerland. pp. 211-239.

Revelo M. (2006). Proyecto de prefactibilidad para la comercialización de maíz. http://repositorio.

ute.edu.ec/bitstream/123456789/6982/1/27776_ 1.pdfConsultado en agosto 2021.

Sámano RMA. (2013). La agroecología como una alternativa de seguridad alimentaria para las comunidades indígenas. Revista mexicana de ciencias agrícolas. 4:1251-1266. 
Sánchez-González JJ; Ruiz-Corral JA; García GM; Ojeda GR; Larios LC; Holland JB; Medrano RM; García-Romero GE. (2018). Ecogeography of teosinte. PloS One. 13: e0192676. DOI: 10.1371/journal.pone.0192676

SIAP. (2019). Servicio de Información Agroalimentaria y Pesquera. Reporte del mercado de maíz. https://www.cima.aserca.gob.mx/work/models/ cima/pdf/cadena/2019/Reporte_mercado_maiz_ 070819.pdf Consultado en agosto 2021.

SIAP. (2020). Servicio de Información Agroalimentaria y Pesquera. https://nube.siap.gob.mx/avance_agricola/ Consultado en agosto 2021.

Skendžić S; Zovko M; Živković IP; Lešić V; Lemić D. (2021). The Impact of climate change on agricultural Insect Pests. Insects. 12: 440. DOI: $10.3390 /$ insects 12050440

Streck NA. (2005). Climate change and agroecosystems: The effect of elevated atmospheric $\mathrm{CO} 2$ and temperature on crop growth, development, and yield. Ciênc. Rural. 35:730-740.

Vela E; Viterí S; Granados M; González A. (2011). El Maíz, de la época prehispánica a la actualidad, alimento y cultura. Arqueología mexicana. 16:97-113.

Zhao C; Liu B; Piao S; Wang X; Lobell DB; Huang Y; Huang M; Yao Y; Bassu S; Ciais P; Durand JL; Elliott J; Ewert F; Janssens IA; Li T; Lin E; Liu Q; Martre P; Müller C; Peng S; Peñuelas J; Ruane AC; Wallach D; Wang T; Wu D; Liu Z; Zhu Y; Zhu Z; Asseng S. (2017). Temperature increase reduces global yields of major crops in four independent estimates. PNAS. 114: 9326-9331. DOI: 10.1073/pnas.1701762114. 